\title{
The growing remit of the EU in environmental and climate change policy and citizens' support across the Union.
}

Jürgen Gerhards \& Holger Lengfeld

Berliner Studien zur Soziologie Europas

Nr. 11

Februar 2008

Freie Universität Berlin, Institut für Soziologie, Garystraße 55, D-14195 Berlin 
Die „Berliner Studien zur Soziologie Europas“ des Lehrstuhls für Makrosoziologie der Freien Universität Berlin verstehen sich als ein Ort zur Vorpublikation von Beiträgen, die später in Fachzeitschriften und Sammelbänden veröffentlicht werden sollen. Die Beiträge sollen helfen, eine Soziologie Europas zu profilieren; sie stehen auch im Kontext des Master-Studiengangs „Soziologie - Europäische Gesellschaften“.

Gegenstand der Reihe sind Beiträge zur Analyse der Herausbildung einer europäischen Gesellschaftsstruktur und -kultur, vergleichende Analysen, die die Unterschiede und Gemeinsamkeiten zwischen verschiedenen europäischen Gesellschaften thematisieren, sowie theoretische Versuche einer Soziologie Europas.

Ziel der Reihe ist es, durch die frühe Verbreitung dieser Arbeiten den wissenschaftlichen Gedankenaustausch zu fördern. Die Beiträge sind nur über das Internet als pdf-Datei zu beziehen.

Zitationsweise: BSSE-Arbeitspapier Nr. 11. Berlin: Freie Universität Berlin.

Dieser Artikel erscheint in „European Journal of Social Policy”. 


\begin{abstract}
In a first step, we reconstruct the emergence and content of European Union climate and environmental policies. These policies have become increasingly important such that today the EU expects member states actively to protect the natural environment even at the price of less economic freedom and higher financial costs. Using 2006 Eurobarometer data, we then analyze the extent to which citizens support this normative idea of environmental protection. Overall, the approval rating for the EU ecological idea is high, and environmental protection is an integral component of European citizens' value system. Nevertheless, not all countries support this to the same degree. Citizens of EU-15 countries show higher levels of support for the environment to take precedence over economic claims than citizens in Accession I and II country groups and in Turkey. As regression analysis show, the level of support depends on several factors. The most important ones are the country's level of economic modernization, and the citizens' generalised political orientations.
\end{abstract}


The European Union's environmental and climate change policy has experienced astonishing developments since the 1970s. Environmental protection was not on the political agenda when the EC was launched in 1957, and only isolated environmental guidelines appeared until the early 1970s. However, environmental protection has become increasingly important since the 1970s (Bailey 2003; Barnes/Barnes 1999; McCormick 1999; Börzel 2007). From then on, the breadth of environmental regulations increased substantially, and environmental protection worked its way up the policy agenda and into the EU's primary law. Nowadays, environmental protection and policies on climate change is equally important as the freedom of movement, the social market economy, and gender equality rights. In this article, we will analyse whether the citizens within the EU support the EU's ideas of environmental protection, and if so, to what extent. In the first section we will give a brief description of the emergence of EU environmental policy from the early 1970's until 2007. Using 2006 survey data, we will analyze in the second section to what extent EU citizens support the idea of environmental protection, and in the third section we will show which factors hold responsible for attitudinal differences on the individual and country's level.

\section{Emergence of a European Union's Environmental Policy}

From its beginnings until 1985, environmental protection was neither included in the European Treaties nor defined in primary legislation as a European task. ${ }^{1}$ The EU expanded its responsibility for environmental questions, however, by a strategy known as "frame-bridging." ${ }^{2}$ In the preamble of the Treaty of Rome, the EU states its objective to improve life and employment conditions for its citizens. The Treaty's creators intended for the term "life conditions" to be viewed in a strict economic light. However, the "frame-bridging" strategy enabled EU institutions to include, step by step, ecological "living standards" as a relevant mission (cf. Knill 2003: 19 ff.; Johnson/Corcelle 1989: 2ff.). With the Single European Act of 1987, the "Treaty for the European Economic Community" expanded and separated environmental policy from other fields. Consequently, environmental policy was given its own Directorate General, which served to underscore the important institutional position of the environment. The Maastricht and Amsterdam Treaties (1993 and 1999, respectively) further strengthened this delineation between environmental policy and other political arenas. The symbolic culmination of these institutional developments is the "Reform Treaty of Lisbon" 2007. The Reform Treaty incorporates additional agreements

1 See Gerhards/Lengfeld (2008) for more details.

2 The concept of "frame-bridging" was developed by David Snow in the context of social movement research (cf. Snow et. al. 1986). 
regarding climate change and the fight against global warming, which have been added as targets for the European Union. In addition, several provisions of the treaties have been amended to include solidarity in matters of energy supply and changes to the energy policy within the European Union.

One of the most important aspects of EU environmental policy is in regard to the community's enlargement. The EU has created a contingency between membership and investment in comprehensive environmental protection. The 1993 Copenhagen criteria insist that every acceding state has to accept the Acquis Communautaire before joining the Union. Chapter 21 of the Acquis covers environmental protection. It provides the basis with which to examine acceding states' compliance with EU environmental policy.

Within the last years, climate policy has become an integral part of EU environmental policy (Anderson et al. 2007; EC 2007a). The European Union has played a key role in the development of the two major treaties, the 1992 "United Nations Framework Convention on Climate Change" and its "Kyoto Protocol", agreed in 1997. In 2000, the Commission launched the "European Climate Change Programme (ECCP)". The ECCP has led to the adoption of a wide range of new policies and measures. In its March 2007 meeting, the European Council made another farreaching decision regarding the combat against climate change. The European Council emphasised the EU's commitment to transform Europe into a highly energyefficient, low greenhouse-gas-emitting economy. The Council defined binding targets by 2020 to: (a) reduce EU emissions by twenty percent regardless of progress made in post-Kyoto Protocol international negotiations, (b) make twenty percent of the EU's overall energy consumption come from renewable energy sources, and (c) decrease EU energy consumption by twenty percent as compared to projections.

In sum, environmental protection and climate policy has become a permanent component of EU policies over the past twenty years. By no means, however, does this imply that the EU as an economically integrated community has been replaced by a community primarily aiming to implement only ecologically-sound policies. Nevertheless, economic criteria have been increasingly supplemented by ecological standards that at times contradict the former. This interaction of ecological and economic has taken the EU's ecological concept beyond abstract ideology; rather, this concept was and is momentous and effective in a number of concrete decisions.

\section{Environmental Attitudes of EU and Acceding State Citizens}

For every policy, however, it is important to ask for its support amongst citizens, and we will do this in the following chapter. To what extent do citizens from different EU-countries support the idea of an EU with a high level of environmental and cli- 
mate protection that may constrain purely economic criteria? Unfortunately, there is no data set available which allows us to analyse attitudes toward EU climate policy. Cognitive dissonance theory (Festinger 1957) has shown, however, that more specific attitudes - like attitudes toward climate policy - are strongly consistent with more general attitudes - such as attitudes toward environmental policy. This argument allows us to analyse a survey in which attitudes toward environmental protection have been asked, and to interpret the findings in the light of the EU's policy. We have analyzed the "Eurobarometer (EB) 66.1" conducted in autumn 2006. The EB 66.1 is one of the most up-to-date surveys containing environmental questions. It has been carried out in all EU-countries, the 2007 acceded states Romania and Bulgaria, and the candidate countries Turkey and Croatia. ${ }^{3}$ To measure how the European citizen's accept the EU's normative idea of climate protection, we have chosen the following question posed to the respondents: "Economic growth must be a priority for our (Name of country), even if it affects the environment." Respondents could choose from four answers: "totally agree", "tend to agree", "tend to disagree", and "totally disagree". This item has two advantages. First, the respondents clearly have to speak out against the priority of ecological over economic claims. Compared with questions which solely ask for the acceptance of environmental protection, the item avoids answers biased by social desirability. Second, agreement or disagreement with the statement is connected with ecological or, alternatively, economic costs for which the individual or the community must pay. We showed in the previous section how ecological ideas were gradually introduced alongside economic issues. The chosen question embodies this aspect quite well. To measure the level of support for EU's environmental policy, we combined the "totally disagree" and "tend to disagree" responses.

3 For methodological details see European Commission $2007 \mathrm{~b}$. 
Figure 1: Percentage of Citizens who disagree that economic growth must be a priority over environmental protection

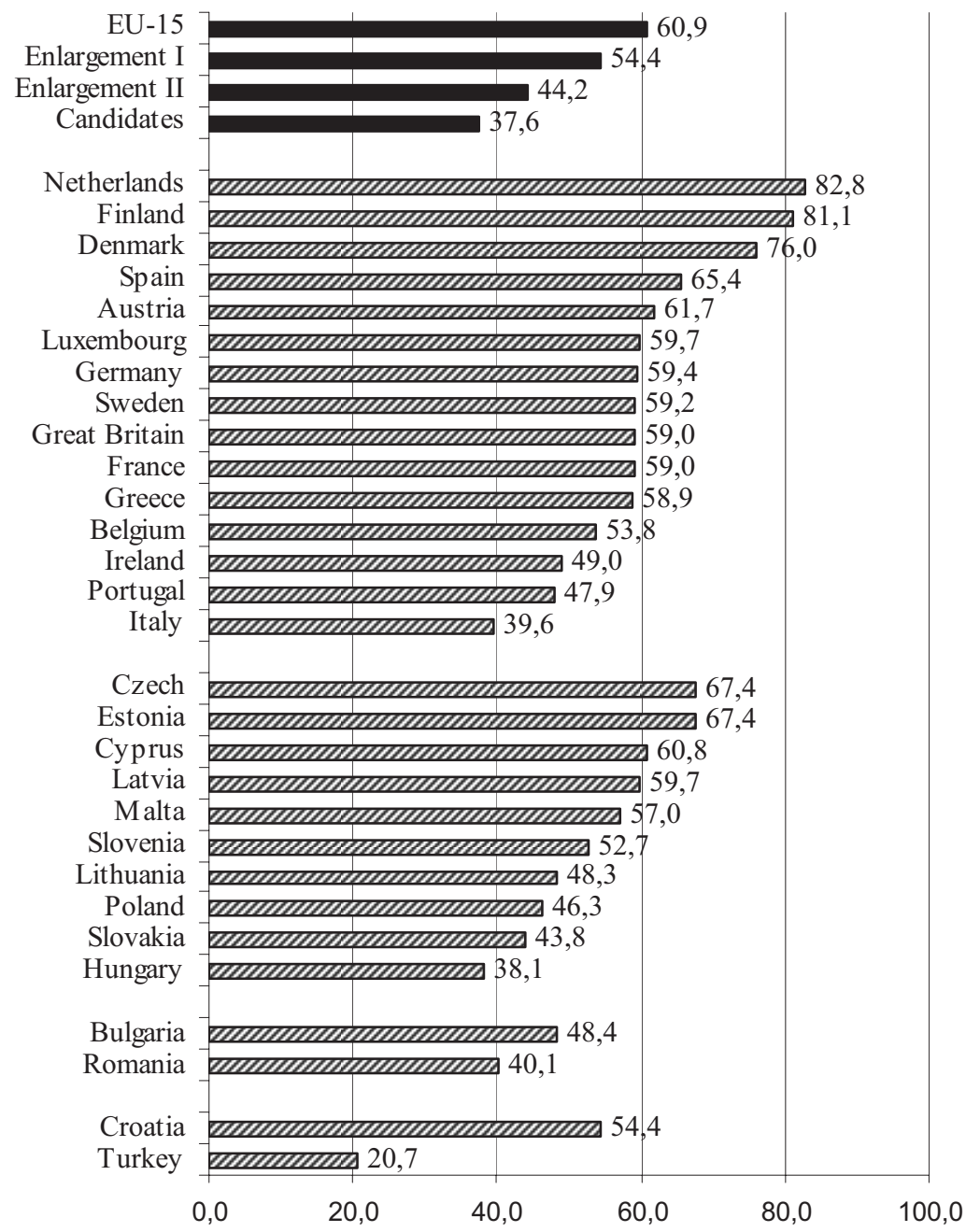

The majority of citizens in 18 of the 28 countries agree to restrict economic growth in favour of environmental protection. There are, however, distinctions in the level of support between the four country groups. Sixty percent of EU-15 citizens give precedence to environmental protection over economic growth; in the Accession I and II countries, the approval rating is fifty-four and forty-four percent, respectively, and thirty-seven per cent in the two candidate countries. The Netherlands and the Scandinavian countries Denmark and Finland have the highest approval rating for environmental protection, whereas Romania, Italy, Hungary, and especially Turkey are at the end of the scale. In Turkey, only slightly more than twenty percent of the respondents disagreed that economic growth should have priority. 


\section{Explaining Attitudes toward the Environment}

Although citizens' approval rating for EU environmental policy is overall rather high, this does not apply equally for all countries. Especially previous EU enlargement has changed the community's overall level of support for environmental protection. However, values are not immutable, and change depends upon the social conditions that mould these attitudes. It is therefore important to analyse which social contexts influence personal beliefs concerning environmental protection. Along other causes, six factors hold responsible for attitudinal differences on the individual and country level.

a. First, higher expenditures for environmental protection increases pressure on the state's budgetary expenditures for competing state programmes (Diekmann/Franzen 1999; Franzen 2003; Gerhards/Lengfeld 2008). We assume that EUcitizens' approval for environmental protection depends upon the economic wellbeing of their country. Consequently, citizens of richer countries (measured by means of the HDI) tend show higher levels of support for environmental protection.

b. People follow not only their material interests but also their ideological orientations and beliefs. The left/right scheme depicts an abstract ideological grid that citizens use to interpret concrete political topics. "Right" is strongly associated with economic development, growth, and national identity. "Left" is associated with equality, solidarity, socialism, and internationalism (Fuchs/Klingemann 1990). As shown by different empirical studies, the left/right schema has also effects on environmental protection attitudes (cf. Preisendörfer 1999: 156; Preisendörfer/Franzen 1996: 228). We assume that people who consider themselves on the left are more likely to support environmental protection, whereas citizens on the right are more likely to oppose environmental protection.

c. Some authors assume that higher environmental consciousness results from poor local and national environmental conditions. Inglehart (1995; 1997) shows that citizens' approve environmental protection measures when higher levels of air pollution emerge in their country. Dunlap (1994; Dunlap et al. 1993), concludes that the worse the environmental conditions are in a local area, region or country, the more sensitive the citizens appear to environmental problems. In contrast, Gerhards and Lengfeld (2008) show that in Europe, preferences for environmental protection increase by rising environmental conditions on the national level.

d. A number of different studies have shown that environmental consciousness fades as people age (Buttel 1979; Greenbaum 1995; Mohai \& Twight 1987). A cohort effect seems to be responsible for this correlation. Socialisation of people born after 1960 took place when environmental damage, such as air and water pollution or the risk of using nuclear energy, were increasingly perceived in the public as societal problems. Environmental issues were barely discussed in public during the socialisation period of people born before 1960. We therefore assume that age, as a proxy 
variable for citizen cohort groups, reveals an independent effect on a respondent's environmental orientation.

d. Finally, we assume more educated interviewees to be more likely to support the protection of the environment than less educated respondents will do (cf. Dietz et al. 1998). Firstly, well educated people are better informed about the negative effects of a damaged environment. Secondly, well educated people are, on average, wealthier than less educated respondents. Because wealthier citizens have fewer budget restrictions when it comes to investing in environmental protection, they will approve environmental protection to a higher degree (cf. Diekmann/Franzen 1999).

Table I shows results of a linear regression analysis based on the Eurobarometer data described above. The results confirm most of our hypotheses.

Table 1: Explaining Attitudes toward the Environment: Priority for Economic Growth over Environmental Protection (Linear Regression)

\begin{tabular}{lcccc}
\hline & Model 1 & Model 2 & Model 3 & Model 4 \\
Individual level & & & & \\
Age & & & & \\
(in Years) & $.053^{*}$ & $.060^{* *}$ & $.068^{* * *}$ & $.070^{* * *}$ \\
Education ${ }^{2}$ & $(2.37)$ & $(3.13)$ & $(4.53)$ & $(4.91)$ \\
Political Orientation & $-.097^{* * *}$ & $-.082^{* * *}$ & $-.078^{* * *}$ & $-.072^{* * *}$ \\
$\left(\begin{array}{l}\text { ( Left; } 10 \text { = Right) } \\
\text { Country Level }\end{array}\right.$ & $-4.44)$ & $(-4.04)$ & $(-6.28)$ & $(-5.58)$ \\
Environmental Quality & $.060^{*}$ & $.062^{*}$ & $.046^{*}$ & $.049^{*}$ \\
(Environmental Sustainability Index & $(2.48)$ & $(2.43)$ & $(2.19)$ & $(2.23)$ \\
ESI) & & & & \\
Degree of Wealth and Modernisation & & $-.120^{*}$ & & -.061 \\
(Human Development Index) & & $(-2.63)$ & & $(-1.45)$ \\
\hline $\mathbf{R}^{2}$ & & & $-.193^{* * *}$ & $-.172^{* *}$ \\
\hline
\end{tabular}

Source: Eurobarometer $66.1 ; \mathrm{N}=10.011$; stepwise extended linear regression models with robust standard errors in consideration of clusters depending on country membership (26 countries); without Luxembourg, Zyprus and Malta because of missing ESI-data. Standardised regression co-efficients are indicated; $\mathrm{t}$-values in brackets; ${ }^{*} \mathrm{p}<.05,{ }^{* *} \mathrm{p}^{<}<.01,{ }^{* * *}$ $\mathrm{p}_{\mathrm{t}}<.001$.

${ }^{1}$ In EB 66.1, education is measured by the year of stopping full-time education.

${ }^{2}$ Because the macro factor ESI and HDI are correlated $(r=.36)$, we have calculated two separate models.

The younger the respondent, the longer he or she spent time in the educational system, and the more he or she holds leftist political orientations, the more he or she speaks out against the domination of economical over ecological claims. Additionally, table 1 shows that support for economical growth increases with lower levels of a country's wealth, measured by Human Development Index (HDI), and its level of 
environmental quality; the latter effect is not significant in the last model, however. Furthermore, a comparison of the independent variables' standardised coefficients shows that the level of wealth and modernisation of a country has the strongest effect on the respective citizens' support for environmental protection.

\section{Conclusion}

One can conclude from our findings that new EU initiatives regarding environmental protection and combating climate change will find support from most of the citizens of the European Union. Nevertheless, not all countries support the initiatives to the same degree. Citizens of EU-15 countries show on average higher levels of support for the environment to take precedence over economic claims than citizens in Accession I and II country groups and in Turkey. Preferences for environmental protection depend, above all else, on a country's degree of economic and ecological modernisation. Accession I and II countries, as well as Turkey, remain significantly behind the older member states in these aspects. If our causal analysis is correct, in the long run this difference could decrease if the expected economic modernisation in the new member states proceeds (Gerhards 2007; 2008). 


\section{References}

Anderson, J., Bowyer, C., Fergusson, M. and Valsecchi, C. (2007) Background Paper on European Actions on Climate Change and Energy. Insitute for European Environmental Policy [http://www.ieep.eu/publications/pdfs/2007/T-PAGE\%20-\%20EU\%20paper.pdf].

Bailey, I. (2003) New Environmental Policy Instruments in the European Union. Aldershot: Ashgate.

Barnes, P.M. and Barnes, I.G. (1999) Environmental Policy in the European Union. Cheltenham etc.: Elgar. Börzel, T. A. (2007) 'Environmental Policy', in P. Graziano and M.P. Vink (eds) Europeanization. New Research Agendas. New York: Palgrave Macmilan.

Buttel, F.A. (1979) 'Age and Environmental Concern: A Multivariate Analysis', Youth and Society 10: 237-256.

Diekmann, A. and Franzen, A. (1999) 'The Wealth of Nations and Environmental Concern', Environment and Behavior 31: 540-549.

Dietz, T., Stern, P.C. and Guagnano, G.A. (1998) 'Social Structural and Social Psychological Bases of Environmental Concern', Environment and Behavior 30: 450-471.

Dunlap, R.E. (1994) 'International Attitudes towards Environment and Development', in H. O. Bergesen and G. Parmann (eds) Green Globe Yearbook of International Co-Operation on Environment and Development. Oxford: Oxford University Press.

Dunlap, R.E., Gallup, G.H. and Gallup, A.M. (1993) 'Of Global Concern: Results of the Health of the Planet Survey', Environment 35: 7-15, 33-39.

European Commission (2007a) EU. Action against Climate Change. The European Climate Change Programme. [http://ec.europa.eu/environment/climat/pdf/eu_climate_change_progr.pdf].

European Commission (2007b) Eurobarometer 66. Public Opinion in the European Union. Report. [http://ec.europa.eu/public_opinion/archives/eb/eb66/eb66_en.pdf]

Festinger, L. (1957) A Theory of Cognitive Dissonance. Stanford, CA: Stanford University Press.

Franzen, A. (2003) 'Environmental Attitudes in International Comparison: An Analysis of the ISSP Surveys 1993 and 2000' Social Science Quarterly 84: 297-308.

Fuchs, D. and Klingemann, H.-D. (1990) 'The Left-Right Schema', in M.K. Jennings and J. van Deth (eds) Continuities in Political Action - A Longitudinal Study of Political Orientations in Three Western Democracies. Berlin/New York: Walter de Gruyter.

Gerhards, J. (2007) Cultural Overstretch? Differences between old and new member states of the EU and Turkey. London and New York: Routledge.

Gerhards, J. (2008) 'Free to move? The acceptance of free movement of labour and non discrimination among citizens of Europe', European Societies 10: 121-140.

Gerhards, J. and Lengfeld, H. (2008) 'Support for European Union environmental policy by citizens of EU-member and accession states', forthcoming Comparative Sociology.

Global Leaders of Tomorrow Environment Task Force, World Economic Forum (2001) 2001 Environmental Sustainability Index. New Haven, CT: Yale Center for Environmental Law and Policy. (http://sedac.ciesin.columbia.edu/es/esi/ESI_01a.pdf, 15 May 2007).

Greenbaum, A. (1995) 'Taking Stock of Two Decades of Research on the Social Basis of Environmental Concern', in M.D. Metha and E. Quellet (eds) Environmental Sociology. North York: Captus Press.

Inglehart, R. (1995) 'Public Support for the Environmental Protection: Objective Problems and Subjective Values in 43 Societies', Political Science and Politics 28: 57-72.

Inglehart, R. (1997) Modernization and Postmodernization. Cultural, Economic, and Political Change in 43 Societies. Princeton: Princeton University Press.

Johnson, S.P. and Corcelle, G. (1989) The Environmental Policy of the European Communities. London: Graham \& Trotman.

Knill, C. (2003) Europäische Umweltpolitik. Steuerungsprobleme und Regulierungsmuster im Mehrebenensystem. Opladen: Leske \& Budrich. 
Mohai, P. and Twight, B.W. (1987) 'Age and Environmentalism. An Elaboration of the Buttel Model using National Survey Evidence', Social Science Quarterly 68: 798-815.

McCormick, J. (1999) 'Environmental Policy', in L. Cram, D. Dinan and N. Nugent (eds) Developments in the European Union. Basingstoke/London: Macmillan.

Preisendörfer, P. (1999) Umwelteinstellungen und Umweltverhalten in Deutschland. Empirische Befunde und Analysen auf der Grundlage der Bevölkerungsumfragen 'Umweltbewußtsein in Deutschland 1991 1998'. Opladen: Leske \& Budrich.

Preisendörfer, P. and Franzen, A. (1996) 'Der schöne Schein des Umweltbewußtseins. Zu den Ursachen und Konsequenzen von Umwelteinstellungen in der Bevölkerung', in A. Diekmann and C.C. Jaeger (eds) Umweltsoziologie. Sonderheft 36 der Kölner Zeitschrift für Soziologie und Sozialpsychologie. Opladen: Westdeutscher Verlag.

Snow, D.A., Rochford, E.B., Worden, S.K. and Benford, R.D. (1986) 'Frame Alignment Processes, Micromobilization, and Movement Participation', American Sociological Review 51: 464-481. 